Liturgia Sacra 24 (2018), nr 1, s. 33-52

DOI: $10.25167 / \mathrm{LitS} / 24(2018) 1 / 33-52$

JAROSŁAW SUPERSON SAC

Wydział Teologiczny, UPJPII

\title{
Istotne skladniki treści czynności liturgicznych sprawowanych według Justyna Męczennika i ich ewolucja ${ }^{1}$
}

Mówiąc o istotnych składnikach treści czynności sprawowanej, a mam na myśli celebrację Mszy Świętej, należy w pierwszym rzędzie sięgnąć do 1 Apologii św. Justyna Męczennika. Gdy w pierwszej połowie XX wieku na dobre rozwija się w Kościele ruch liturgiczny, tak jak i wiele innych ruchów odnawiających Kościół, po publikacji pierwszej encykliki dotyczącej liturgii, Mediator Dei autorstwa Piusa XII, w 1947 roku, organizuje się i zbiera w Asyżu w 1956 roku Pierwszy Międzynarodowy Kongres Duszpasterstwa Liturgicznego. Podczas tego kongresu głos zabrał Niemiec, jezuita, spowiednik papieża Piusa XII² i profesor Papieskiego Instytutu Biblijnego Agostino Bea (zm. 1968 r.). W swoim wystąpieniu, będąc już wówczas konsultorem w Świętej Kongregacji Rytów, wskazał on, że opis sprawowanej Eucharystii autorstwa Justyna jest pierwszym kompletnym jej zapisem, a jej liturgiczny schemat został zbudowany z trzech elementów: lektury biblijnej, wyjaśnienia i ofiary eucharystycznej ${ }^{3}$. W niniejszej prezentacji chcę zwrócić uwagę na treści związane z liturgią słowa.

Zanim poddam analizie ten element, w tym miejscu należy podać kilka informacji o tym autorze i jego wyjątkowym dziele. Justyn urodził się około 100 roku we Flaria Neapolis (dawne Sychem a dzisiejsze Nablus) w rodzinie pogańskiej pochodzącej z Grecji, która osiedliła się na terenach Palestyny. Jako osoba do-

\footnotetext{
${ }^{1}$ Niniejszy artykuł dedykuję Czcigodnemu Profesorowi Jackowi Przemysławowi Nowakowi SAC z okazji sześćdziesiątej rocznicy urodzin.

2 Por. R. DE MatTeI, Sobór Watykański II: historia dotad nieopowiedziana, thum. S. Orzeszko, Centrum Kultury i Tradycji Wiedeń 1683, Ząbki 2012, s. 121.

${ }^{3}$ Por. A. BEA, Il valore pastorale della Parola di Dio nella sacra liturgia, w: La restaurazione liturgica nell'opera di Pio XII. Atti del Primo Congresso Internazionale di Liturgia Pastorale - Assisi - Roma 18-22 settembre 1956, Centro di Azione Liturgica, Genova 1957, s. 98.
} 
rosła szukał wiedzy wśród ówczesnych filozofów, ale spotkanie z tajemniczym starcem, prawdopodobnie w okolicach Efezu, przekonało go do lektury pism proroków i zbliżyło do chrześcijaństwa ${ }^{4}$. Jak podaje profesor UKSW Leszek Misiarczyk, „czas i miejsce nawrócenia Justyna pozostają nam niestety nieznane. Miało to miejsce być może gdzieś na wschodzie cesarstwa (...) w latach dwudziestych II wieku"'. Po przybyciu do Rzymu założył on szkołę filozoficzną, która inspirowała się chrześcijaństwem i której siedziba mieściła się nad termami (balneum Timothinum $)^{6}$. O wykorzystywaniu przestrzeni term przez chrześcijan świadczy titulus Pudensa ${ }^{7}$. Szkoła założona przez Justyna musiała być dosyć znana i odnosić jakieś sukcesy, skoro jeden z filozofów, niejaki Krescens, wystąpił przeciwko jej założycielowi.

Właśnie w Rzymie, gdzie Justyn mieszkał do śmierci ok. 165 r., powstają Apologie $^{8}$. Celem Apologii pierwszej, napisanej przez Justyna około 153 r. ${ }^{9}$, jest umożliwienie poznania chrześcijaństwa ówczesnemu rzymskiemu cesarzowi Antoninowi Piusowi (zm. 161 r.), a także jego następcy i rzymskiemu senatowi, a zarazem zapobieżenie prześladowaniu chrześcijan ${ }^{10}$. W tym dziele znajdujemy dwa opisy sprawowania Eucharystii. W pierwszym Eucharystię poprzedza chrzest (por. 1 Apologia 65-66). W drugim jest mowa o niedzielnej Eucharystii (por. 1 Apologia 67). Jak podkreśla Ferdinand Hahn, ta chrześcijańska literatura po raz pierwszy świadczy o oddzieleniu posiłku rytualnego - Eucharystii - od posiłku powszechnego ${ }^{11}$.

${ }^{4}$ Por. B. Altaner, A. Stuiber, Patrologia. Życie, pisma i nauka Ojców Kościoła, tłum. P. Pachciarek, Warszawa 1990, s. 128.

${ }^{5}$ L. MisiarczyK, Wstep, w: Justyn męCZennik, 1 i 2 Apologia. Dialog z Żydem Tryfonem, thum. i oprac. L. MisiarCZYK, Warszawa 2012, s. 8.

${ }^{6}$ Por. G. De SpIRIto, "Balneum Timothinum", w: Lexicon topographicum urbis Romae, E.M. SteInBy (red.), t. I, Quasar, Roma 1993, s. 165-166.

${ }^{7}$ Por. B. FilarsKa, Poczatki architektury chrześcijańskiej (Źródła i monografie, t. CXII), Lublin 1983, s. 31.

${ }^{8}$ Por. L. MisiarczyK, Wstęp, w: Justyn męCZennik, 1 i 2 Apologia, s. 9, 18.

9 Por. E. Bosio, E. Dal Covolo, M. Maritano, Introduzione ai Padri della Chiesa. Secoli I e II (Strumenti della Corona Patrum, t. I), Torino 1990, s. 166.

${ }^{10}$ Por. Euzebiusz z Cezarei, Historia kościelna, thum. A. Caba na podstawie thum. A. Lisieckiego, (Źródła myśli teologicznej, t. LXX), Kraków 2013, s. 266-267; J.J. JANICKI, Slużba Boża w pierwszych wiekach Kościoła. Wybrane zagadnienia, Kraków 2011, s. 16; H.W. AtTRIDGE, Chrześcijaństwo od zburzenia Jerozolimy do cesarza Konstantyna (lata 70-312), w: H. SHANKs (red.), Chrześcijaństwo a judaizm rabiniczny. Historia początków oraz wczesnego rozwoju (Podręczniki biblijne, t. II), thum. W. Chrostowski, Warszawa $2016^{2}$, s. 308.

${ }^{11}$ Por. F. Hahn, Il servizio liturgico nel cristianesimo primitivo, thum. G. Cecchi, (Studi biblici, t. XX), Brescia 1972, s. 102. 


\section{Lektura biblijna}

Co do biblijnej lektury podczas sprawowanej Eucharystii św. Justyn odnotował: „Czyta się wtedy Pamiętniki Apostolskie albo pisma prorockie, dopóki czas na to pozwala" (1 Apologia 67.3). Niestety, nie mamy dokładniejszych informacji na temat struktury i przebiegu liturgii słowa niż to, co odnotowano w tym zdaniu. Anaginoskon (lektor) jest tym, który czyta wskazane księgi, ale trudno jest powiedzieć, czy termin ten wskazuje na urząd, który otrzymał i który realizuje na rzecz wspólnoty ${ }^{12}$. Ów grecki termin oznacza po prostu tego, który czyta, i według Victora Saxera nie jest określeniem tego, który otrzymał funkcję, posługę lektora na rzecz wspólnoty ${ }^{13}$. Wyróżnienie lektora w zapisie, jak podkreśla Gerard Siwek (zm. 2015 r.), wskazuje, że przewodniczący liturgii ma oddzielną pozycję, rolę i miejsce ${ }^{14}$.

Uwydatnienie lektora w zapisie nasuwa szereg pytań. Czy wspólnota gromadząca się na cotygodniową Eucharystię utworzyła na tę okazję serię lektur? Co motywowało wybór pism prorockich do lektury, a co wybór lektury Pamiętników Apostolskich? Kto dokonywał tego wyboru? Czy do tej liturgii używano jakiegoś pulpitu czy ambony? Czy czytano, używając zwoju czy kodeksu? Jaka relacja zachodziła między lekturą a dziękczynieniem wyrażanym przez przełożonego zgromadzenia? Wszystkie te pytania wpisują się w trudny do opisania proces tworzenia się schematu Mszy Świętej i jej lekcjonarza.

Komentatorzy przytoczonego tekstu św. Justyna, Marcel Metzger i Normand Bonneau, zwracają uwagę na część niedzielnej liturgii zbudowaną z czytania Starego Testamentu albo Ewangelii ${ }^{15}$. Ich lektura nie odbywała się w sposób współcześnie nam znany. Kościół nie miał jeszcze wówczas ustalonego lekcjonarza ${ }^{16}$ i była zapewne pewna dowolność w wyborze lektur. Josef Jungmann uważa, iż w tym

12 Por. B. NADOLSKI, Ewangeliarz - więcej niż księga święta: szacunek wobec księgi Ewangelii, Poznań 2000, s. 8.

13 Por. V. SAXER, L'organizzazione delle Chiese ereditate dagli apostoli (70-180), w: L. PIETRI, (red.), Storia del cristianesimo. Religione - Politica - Cultura, t. I, Il Nuovo Popolo (dalle origini al 250), thum. M. Zapella, Borla / Città Nuova, Roma, s. 396.

${ }^{14} \mathrm{G}$. SiweK, Interpretacja homiletyczna miejsc przepowiadania $w$ przestrzeni kościelnej, w: W. PrZYCZYNA (red.), Liturgia i przepowiadanie (Redemptoris missio, t. XXIX), Kraków 2010, s. 61.

15 Por. M. Metzger, Storia della Liturgia Eucaristica. Origine ed evoluzione della più importante celebrazione della vita cristiana, thum. O. Mendolia Gallino, P. Ambrosino, Torino 2003, s. 46; N. Bonneau, Il Lezionario domenicale. Origine struttura teologia, thum. R. Fabbri, (Studi e ricerche di liturgia), Bologna 2012, s. 21-22.

${ }^{16}$ Por. C.S. Mosna, Storia della domenica dalle origini fino agli inizi del V secolo. Problema delle origini e sviluppo. Culto e riposo. Aspetti pastorali e liturgici (Analecta Gregoriana, t. CLXX. Series Facultatis Historiae Ecclesiasticae: sectio B, nr 28), Roma 1969, s. 110; W. DudZIK, Liturgia stowa pierwszych chrześcijan, „Teofil” (2007) nr 1 (25), s. 126. 
antycznym zapisie jest mowa nie tylko o włączeniu lektury pism do sprawowania Eucharystii, ale także o nieuczestniczeniu chrześcijan w synagogalnej liturgii słowa. Według tego historyka liturgii, lektura Pisma u chrześcijan była długa, gdyż czytano więcej niż tylko jeden rozdział z Księgi ${ }^{17}$.

Justyn, co warto odnotować, nie wspomina nic o śpiewie psalmu podczas lektury, a lektura pism prorockich w czasie Eucharystii nie tylko oddaje ówczesną znaną już praktykę, ale także wskazuje na odczytywanie Starego Testamentu i jego interpretacji w środowisku nowotestamentalnym w momencie sprawowania Eucharystii. Pisma prorockie, o których mowa, pomagały więc w budowaniu relacji z Jezusem Chrystusem ${ }^{18}$. Kilkadziesiąt lat później, w Didaskaliach z III wieku, będzie mowa o porównywaniu Prawa i Proroków z Ewangelią, ,jak ze sobą się zgadzają"19.

Inspiracji do praktyki cotygodniowej lektury pism przez chrześcijan można dopatrywać się w zwyczaju znanym z synagogi. Kościół kontynuuje tradycję hebrajską ${ }^{20}$. Renato De Zan nie ma wątpliwości, że chrześcijański zwyczaj liturgiczny ma związek z szabatową synagogalną liturgią. Badacz ten, prowadzący wykłady na temat krytyki i hermeneutyki tekstów liturgicznych na Papieskim Instytucie Liturgicznym im. św. Anzelma w Rzymie ${ }^{21}$, przypomina, że ówczesna liturgia synagogalna była zbudowana z perykopy z Pentateuchu, fragmentu z Proroków i przepowiadania. Liturgia chrześcijańska w II wieku oddaliła się od tego synagogalnego porządku, zastępując proklamację perykopy z Pentateuchu fragmentem z Pamiętników Apostolskich - Ewangelii ${ }^{22}$.

Co do czasu trwania liturgii słowa Justyn odnotował, że czytano, „dopóki czas na to pozwalał" (1 Apologia 67.3). Prawdopodobnie jakieś zewnętrze przeciwności, jak twierdzi Willy Rordorf, wpływały na niemożność czytania do woli pism apostołów albo proroków podczas tych zgromadzeń. Przeciwnością taką mogła być

17 Por. J.A. Jungmann, Liturgia pierwotnego Kościoła do czasów Grzegorza Wielkiego, thum. T. Lubowiecka, (Modlitwa Kościoła, t. XVI), Kraków 2013, s. 74.

18 Por. N. Bonneau, Il Lezionario domenicale, s. 21-22.

19 Didaskalia, czyli Katolicka nauka dwunastu apostołów $i$ świętych uczniów Zbawiciela naszego, w: M. MichaLSKI, Antologia literatury patrystycznej, t. I, Warszawa 1975, s. 320.

${ }^{20}$ Por. Сh. Perrot, La lecture de la Bible dans les synagogues du premier siècle de notre ère, „La Maison-Dieu” (1976) nr 126, s. 24-41; J.J. Von Allmen, Celebrare la salvezza. Dottrina e prassi del culto cristiano. Presentazione P. Tamburrino, tłum. L. Melotti, Editrice Elle di Ci, Leumann, Torino 1986, s. 110; H. Hoping, Il mio corpo dato per voi. Storia e teologia dell'eucaristia, tłum. V. Maraldi, (Biblioteca di Teologia Contemporanea, t. 173), Queriniana, Brescia 2015, s. 71.

${ }^{21}$ Por. Pontificio Ateneo s. Anselmo, Ordo anni academici 2012-2013, Roma 2012, s. 206, 218.

${ }^{22}$ Por. R. DE ZAN, Leggere la Bibbia nella liturgia, „Rivista Liturgica” LXXXVIII (2001), s. $870-871$. 
konieczność powrotu na czas do pracy ${ }^{23}$. Ten obowiązek pracy mógł pomóc w wypracowaniu pory sprawowania Eucharystii. Zatem pora sprawowania Eucharystii, jednego aktu kultu zbudowanego z dwóch zasadniczych części, z liturgii słowa i liturgii eucharystycznej ${ }^{24}$, ma związek z czasem, czego rezultatem jest, przypisanie jej do godzin porannych ${ }^{25}$. W pierwszych wiekach chrześcijanie bardzo często gromadzili się rankiem na łamanie chleba ${ }^{26}$.

Nauka Dwunastu Apostołów mówi o gromadzeniu się w Dzień Pański na łamanie chleba i składanie dziękczynienia (por. Didache 14), ale nic nie mówi o lekturze biblijnej, która by tę czynność poprzedzała. Szukając źródeł dla poznania ewolucji liturgii słowa, należy sięgnąć do Tertuliana (zm. po 225 r.), „ojca łacińskiego typu chrześcijaństwa"27, który przesłanie nauki Chrystusa zaczął wyrażać w duchu i tradycji kultury łacińskiej ${ }^{28}$. W swoim antygnostyckim dziele De anima, napisanym w latach 211-212, posługując się wiedzą filozoficzną i medyczną ${ }^{29}$, odnotowuje on cechy duszy, która związana jest z organizmem cielesnym (por. De anima 6):

Zgodnie z tym, jak czytane są Pisma, śpiewane Psalmy, wypowiadane przemowy i kierowane prośby, dostarczają one [duszy] materiału do wizji (De anima 9$)^{30}$.

Zacytowany tekst mówi, że Scripturae leguntur, Psalmi canuntur, adlocutiones proferuntur i petitiones delegantur. Wszystkie te elementy spotykamy chociażby we współczesnej liturgii słowa, która jest częścią Mszy Świętej. Wszystkie wykonuje się $\mathrm{z}$ ambony (por. OWMR 55, 58, 71, 309) ${ }^{31}$. Terminy użyte w tym antycz-

${ }^{23}$ Por. W. RoRdorf, Sabato e domenica nella Chiesa antica (Traditio Christiana, t. II), Torino 1979, s. 137-139.

${ }^{24}$ Por. J.J. Kopeć, Eucharystia w życiu Kościoła pierwszych wieków, w: J.J. Kopeć (red.), Eucharystia: misterium, ofiara, kult. Materiały z sympozjów: sekcji wykładowców liturgiki (Włocławek 11-12.09.1996 r.) i Instytutu Formacji Pastoralno-Liturgicznej KUL (Lublin, KUL, 10.04.1997 r.), z okazji 46. Międzynarodowego Kongresu Eucharystycznego we Wrocławiu, Lublin 1997, s. 54.

${ }_{25}$ Por. D.N. Power, Il mistero eucaristico. Infondere nuova vita alla tradizione, thum. G. Volpe, (Biblioteca di Teologia Contemporanea, t. 93), Brescia 1997, s. 99.

${ }^{26}$ Por. J.A. Superson, Pora Mszy św. w pierwszych wiekach chrześcijaństwa, ,Liturgia Sacra” 15 (2009) $\mathrm{nr}$ 1, s. 10-13.

27 M. Michalski, Antologia literatury patrystycznej, t. 1, s. 208.

${ }_{28}$ Por. tamże, s. 208; M. SimonetTi, Alcuni aspetti del linguaggio teologico da Tertulliano ad Agostino, w: E. Dal Covolo, M. Sod, (red.), Il latino e i cristiani. Un bilancio all'inizio del terzo millenio (Monumenta Studia Instrumenta Liturgica, t. XVII), Città del Vaticano 2002, s. 187.

29 Por. E. Bosio, E. Dal Covolo, M. Maritano, Introduzione ai Padri della Chiesa. Secoli II e III (Strumenti della Corona Patrum, t. II), Torino 1991, s. 120-121.

${ }^{30}$ Quintus Septimus Florens Tertullianus, De anima, PL, t. II, kol. 660.

${ }^{31}$ Skrót OWMR - Ogólne wprowadzenie do Mszału Rzymskiego. Z trzeciego wydania Mszału Rzymskiego, Rzym 2002, oraz Wskazania Episkopatu Polski, Poznań 2006. 
nym tekście, tak bliskie badaczom związanym z teologią liturgiczną ${ }^{32}$, skłaniają do podjęcia refleksji nad zacytowanym fragmentem. Rodzi się bowiem pytanie, czy Tertulian ma na myśli konkretną znaną mu liturgię, którą przybliża czytelnikowi swojego dzieła, czy też nie. Innymi słowy: czy na początku III wieku świadczy już o usystematyzowanej liturgii słowa i o jakimś nieodnotowanym i nienazwanym przez siebie miejscu jej wykonywania?

Tekst przedstawiony wyżej jest różnie komentowany przez liturgistów. Francuski liturgista Aimé Georges Martimort (zm. 2000 r.) dostrzega w nim opis niedzielnego rytuału odprawianego około $210 \mathrm{roku}^{33}$, a opracowujący ostatnio źródła afrykańskiego dziedzictwa chrześcijańskiego Claudio Moreschini i Pietro Podolak mówią o niedzielnej liturgii w środowisku montanistów, która ich zdaniem była w swojej istocie identyczna z katolicką. Badacze ci, korzystając także z dzieła Tertuliana (Apologetyk 39.3-4), uważają, że adlocutiones mogły być wygłaszane także przez osoby świeckie, a petitiones były swoją formą zbliżone do modlitwy wiernych ${ }^{34}$. Także niedawno na łamach włoskiego czasopisma „Rivista Liturgica" Cristina Simonelli wnioskuje, że zapis ten wskazuje na liturgię eucharystyczną związaną ze środowiskiem montanistów. Po zakończeniu tej celebracji, gdy wezwano do rozejścia się, pewna siostra na bazie usłyszanych pism, psalmów, przemówień i próśb wyartykułowała prorocką wizję. $Z$ tekstu wynika, że wizja była pilnie badana przez kogoś (raczej był to mężczyzna), kto miał prawo ją zaaprobować lub nie ${ }^{35}$.

Oddając głos naszym rodzimym badaczom, zauważamy, że Jan Miazek mówi o chrześcijańskiej niedzielnej liturgii nierzymskiej, to jest pochodzącej z północnej Afryki, z Kartaginy ${ }^{36}$. Liturgista Bogusław Nadolski, w swoim podręczniku do liturgiki, komentując zacytowany fragment, widzi w nim wczesnochrześcijańską liturgię zbudowaną na triadzie: „czytanie - śpiew - modlitwa”37. Helmut Jan

32 Proponuję, aby Czytelnik w celu zrozumienia, co kryje się pod nomenklaturą „teologia liturgiczna", zapoznał się z publikacją: B. Migut (red.), Teologia liturgiczna. W poszukiwaniu syntezy w teologii, Wydawnictwo KUL, Lublin 2013.

33 Por. A.G., Martimort, La Chiesa in preghiera. Introduzione alla Liturgia. Edizione rinnovata, t. I, Principi della liturgia, tłum. A. Biazzi, Brescia 19952, s. 165.

${ }^{34}$ Por. Quintus Septimus Florens Tertullianus, De anima, w: tenże, Opera dogmatica: De anima - De carnis resurrectione - Adversus Praxean, C. Moreschini, P. Podolak, (red.), (Scriptores Arficae Christiani, t. III/2.b), Città Nuova, Roma 2010, s. 76-77.

${ }_{35}$ Por. C. Simonelli, Prendere parola nella liturgia. Piste di ricerca, „Rivista Liturgica” CIV (2017), s. 51.

${ }^{36}$ Por. J. MiAzeK, Liturgia w czasach Ojców Kościoła, „Warszawskie Studia Teologiczne” XX (2007) nr 1, s. 160.

37 B. NAdolski, Liturgika, t. IV, Eucharystia, Poznań 2011², s. 193. 
Sobeczko, powołując się na De anima 9 , odnotowuje fakt przejęcia przez chrześcijan z synagogi zwyczaju śpiewania psalmu ${ }^{38}$.

Obecność psalmu po lekturze odnotowana w De anima 9 prowokuje pytania $^{39}$. Czy specjalistyczne badania nad liturgią synagogalną z końca II i początku III wieku są w stanie wykazać obecność psalmów wykonywanych wspólnie przez Żydów w synagogalnym zgromadzeniu podczas szabatu (nie indywidualnie, nie w gronie rodzinnym)? Trudno wykazać, co delikatnie wzmiankuje Felice Rainoldi (zm. 2015 r.) w Traditio canendi, że De anima 9 świadczy z całą pewnością o korzystaniu z psalmów znanych nam ze Starego Testamentu ${ }^{40}$. Psalmami do III czy IV wieku nazywano także kompozycje niebiblijne. Robert Taft dostrzega to, powołując się właśnie na Tertuliana i jego dzieło Przeciw Marcjonowi ${ }^{41}$. Apostołowie Piotr i Jan po złożeniu świadectwa przed Sanhedrynem (por. Dz 4,1-22) i powrocie „do swoich” (Dz 4,23), opowiadając im, „co do nich mówili arcykapłani i starsi" (Dz 4,23), uczestniczyli w modlitwie wyznawców Chrystusa. Ci wyznawcy, członkowie Kościoła pierwotnego, jako tekst modlitwy wznieśli psalmiczny centon, zbudowany z wersetów Ps $146(145), 6$ i Ps 2,1 n. (por. Dz 4,2426). Albert Gerhards podkreśla, że chociaż zwyczaj wspólnej modlitwy psalmami był znany wyznawcom Jezusa Chrystusa, o czym świadczy wyżej wskazana perykopa, to nie pochodzi on z praktyki synagogalnej ${ }^{42}$. W renomowanej publikacji Paula Bradshawa The Search for the Origins of Christian Worship, ostatnio przetłumaczonej na język polski, przytaczającej między innymi rezultaty badań

38 Por. H.J. SobeczKo, Liturgia słowa Bożego w tradycji rzymskiej do reformy II Soboru Watykańskiego, w: A. ŻĄDŁo (red. nauk.), Praedicamus Christum crucifixum. Słowo Boże w liturgii Kościoła. Księga Jubileuszowa dedykowana Księdzu Arcybiskupowi Damianowi Zimoniowi Metropolicie Katowickiemu w 25. rocznicę święceń biskupich, Księgarnia św. Jacka, Katowice 2010, s. 109; H.J. SobeczKo, Słowo Boże w tradycji Kościoła sprawujacego liturgie, w: A. ŻĄDŁo (red.), Słowo Boże w liturgii $i$ życiu Kościoła (Kościół w Trzecim Tysiącleciu, t. V), Katowice 2006, s. 44.

39 Sokrates Scholastyk podaje, że zwyczaj antyfonalnego śpiewania hymnów do liturgii wprowadził Ignacy Antiocheński. Por. Sokrates Scholastyk, Historia Kościoła, tłum. S. Kazikowski, Warszawa 1972, s. 409. Natomiast z lektury Liber pontificalis wynika, że papież Celestyn wprowadził do liturgii antyfoniczne śpiewanie psalmów przed złożeniem Ofiary. Por. M. Ożóg, H. PIETras (oprac.), Księga pontyfików 1-96 (do roku 772) (Synody i kolekcje praw, t. IX), tłum. P. Szewczyk, M. Jesiotr Kraków 2014, s. 105-105*.

40 Por. F. Rainoldi, Traditio canendi. Appunti per una storia dei riti cristiani cantati (Bibliotheca Ephemerides Liturgicae. Subsidia, t. CVI), C.L.V., Roma 2000, s. 47.

41 Por. Tertulian, Przeciw Marcjonowi V.8.12; Tertulian, Przeciw Marcjonowi, thum. S. Ryzner, wstęp, oprac. W. Myszor, (Pisma Starochrześcijańskich Pisarzy, t. LVIII), Warszawa 1994, s. 278; R.F. TAFT, A partire dalla liturgia. Perché è la liturgia che fa la Chiesa (Pubblicazioni del Centro Aletti), tłum. S. Staffuzza, Lipa Edizioni, Roma 2004, s. 165.

42 Por. A. Gerhards, La liturgia della nostra fede, tłum. G. Colosio, (Liturgia e vita), Magnano 2010, s. 68. 
Jamesa McKinnona, twierdzi się, że codzienne odmawianie psalmów w synagodze pojawi się dopiero w VIII wieku ${ }^{43}$.

Antyczny tekst De anima 9 nie pomaga w jednoznacznym wskazaniu miejsca, skąd czytano pisma i śpiewano psalmy i kto te czynności wykonywał. Ponadto, przy założeniu, że zawarta w nim jest wzmianka o korzystaniu z psalmów starotestamentalnych, nasuwa się pytanie: kto „poinstruował” chrześcijan, jaki autorytet zaważył, że włączyli oni starotestamentalne psalmy do swojej wspólnotowej eucharystycznej liturgii po przeczytanej perykopie? Wydaje się, że odpowiedź jest umieszczona na kartach Nowego Testamentu. Odczytywanie ich w sposób chrystologiczny, nadanie im właśnie tego nowego charakteru, pozwoliło na przyjęcie ich do chrześcijańskiej modlitwy prywatnej i liturgicznej ${ }^{44}$.

\section{Przepowiadanie}

„Przełożony wspólnoty słowem upomina i zachęca nas do naśladowania tych pięknych nauk" (1 Apologia 67.4). Justyn Męczennik podaje, że przepowiadanie miało miejsce po odczytaniu przez lektora pism. To najstarszy dowód praktyki przepowiadania po przeczytanej lekturze. Autor odnotowuje ten fakt, ale nie podaje treści przepowiadania ${ }^{45}$. Właściwość przepowiadania przełożonego została zdefiniowana jako wyartykułowanie przez niego upomnień i zachęt, by pobudzić słuchacza do naśladowania nauk. Ich źródłem były pisma proroków albo ewangelie i zapewne dotyczyły one treści kerygmatyczych i wskazań religijno-moralnych ${ }^{46}$.

Przepowiadanie liturgiczne było oddane przełożonemu zgromadzenia, co charakteryzuje jego szczególną rolę ${ }^{47}$, i zdaje się wskazywać już na jakieś normatywne podstawy tej funkcji na rzecz zgromadzenia. Była to ta sama osoba, jak zaznacza Justyn, która zanosiła długą modlitwę eucharystyczną ${ }^{48}$. Samo zaś przepowiadanie

${ }^{43}$ Por. P.F. Bradshaw, W poszukiwaniu początków kultu chrześcijańskiego. Źródła i metody badań wczesnej liturgii (Źródło i szczyt), tłum. P. Kaznowski, M. Koza, Kraków 2016, s. 83.

${ }^{44}$ Por. A. Gerhards, La liturgia della nostra fede (Liturgia e vita), thum. G. Colosio, Magnano 2010, s. 69.

45 Por. K. Panuś, Historia kaznodziejstwa, Kraków 2007, s. 30.

${ }^{46}$ Por. tamże, s. 25.

${ }^{47}$ Por. J.A. Jungmann, La Messa nel corso dei secoli. La Messa e la comunità della Chiesa. La Messa didattica, thum. Benedittine del Monastero di. S. Paolo in Sorrento, t. I, Torino 1963², s. 366.

${ }^{48}$ Por. D. SARtore, “Chiesa e predicazione”, w: M. Sodi, A. Triacca (red.), Dizionario di omiletica, Torino 2013, s. 263. 
odbywało się prawdopodobnie od miejsca przewodniczenia, na co wskazują chociażby następne wieki, kiedy to z katedry ustawionej w bazylikach przewodniczył i przepowiadał biskup ${ }^{49}$.

Szukając źródeł chrześcijańskiego przepowiadania, warto przypomnieć dwie sytuacje dobrze nam znane z lektury Nowego Testamentu. W Ewangelii św. Łukasza czytamy, że Jezus Chrystus w synagodze w Nazarecie w dzień szabatu po odczytaniu haftary wyraził w swoim dereszu nie upomnienie, ale wręcz ostrą krytykę słuchaczy, swoich ziomków (por. Łk 4,16-30), którzy ,nie słuchali Jezusa z wiarą, lecz powątpiewali, by Bóg mógł przemówić do nich przez dobrze znanego im rodaka" ${ }^{50}$. Natomiast św. Paweł (zm. 63/64 r.) w synagodze w Antiochii Pizydyjskiej w szabat „po odczytaniu Prawa i Proroków” (Dz 13,15) wygłosił „słowo zachęty dla ludu" (Dz 13,15).

Trudno pokazać relację zachodzącą między liturgią słowa a składanym długim dziękczynieniem. Kilka lat temu Stanisław Czerwik napisał:

\begin{abstract}
Brak jeszcze w najstarszej tradycji pogłębionej refleksji teologicznej na temat więzi łączącej obie części liturgii, ale stopniowo powstaje koncepcja „dwóch stołów”. Podstawą tej koncepcji będzie refleksja nad darem manny zsyłanym Izraelitom podczas wędrówki przez pustynię (por. Wj 16,4.13n.) oraz nad typologią tego daru w mowie Jezusa po rozmnożeniu chleba (por. J 6,31-32.48-51; także Pwt 8,3; Mt 4,4). W tym kontekście pojawiają się wypowiedzi ojców na temat słowa Bożego jako chleba, który chrześcijanom jest niezbędny do życia i winien być traktowany z takim samym szacunkiem jak Chleb eucharystyczny ${ }^{51}$.
\end{abstract}

Niemniej jednak, czytając 1 Apologię, trzeba zauważyć, że tak jak lektura pism jest źródłem nauk wypowiadanych przez przełożonego zgromadzenia, tak i przekaz zostawiony w ewangeliach dotyczący sprawowania Eucharystii jest nakazem, który obliguje wspólnotę Kościoła do jej celebrowania. Czyni to przełożony w długim dziękczynieniu nad chlebem i kielichem wypełnionym wodą i winem, po którym lud odpowiada: Amen. Owocem tego dziękczynienia jest pokarm, rozdawany tak obecnym, jak i nieobecnym, który zwie się Eucharystią. W ten sposób nakaz

49 Por. G. SiweK, Interpretacja homiletyczna miejsc, s. 61.

50 F. Mickiewicz (red.), Ewangelia według Św. Łukasza. Rozdziały 1-11. Wstęp. Przekład z oryginatu. Komentarz, część I, (Nowy komentarz biblijny. Nowy Testament, t. III/1), Częstochowa 2011, S. 263 .

51 S. Czerwik, Wiara w obecność Chrystusa w sprawowaniu Eucharystii. Perspektywa historyczna, w: S. KopereK (przew. zesp. red.) Eucharystia na oltarzu świata (Studia, t. XIV), Kraków 2006, s. 180-181. 
zostawiony $\mathrm{w}$ ewangeliach jest aktualizowany $\mathrm{w}$ sprawowanej liturgii $\mathrm{w}$ dniu zwanym dniem Słońca albo w dniu udzielania chrztu. Jak widać, pisma dla Justyna nie są materiałem narracyjnym, ale słowem Bożym, które przyjęte i poddane refleksji konstytuuje akcję składania długiego dziękczynienia i nadaje jej prawowierność. Domenico Sartore zauważa, że w liturgii eucharystycznej najpierw następuje „łamanie słowa Bożego", a następnie „łamanie chleba" ${ }^{2}$. Obie te czynności nie kończą się w chwili dokończenia gestu „łamania”, ale zmierzają do karmienia wiernych słowem Bożym oraz Ciałem i Krwią Chrystusa.

Najstarsze teksty przepowiadania, jakie posiadamy, to homilia z pierwszej połowy II wieku, a więc napisana przed apologiami św. Justyna, zwana dawniej Drugim listem do Koryntian św. Klemensa ${ }^{53}$ i Homilia paschalna Melitona z Sardes ${ }^{54}$, napisana między 160 a 170 rokiem i odczytana prawdopodobnie zaraz po wysłuchaniu fragmentu z Księgi Wyjścia w czasie liturgii eucharystycznej, podczas której udzielano sakramentów inicjacji ${ }^{55}$. W pierwszej homilii, czyli Drugim liście do Koryntian św. Klemensa, spotykamy treści chrystologiczne, kerygmatyczne oraz nauki dotyczące moralności.

\section{Oratio universalis}

W 1 Apologii jest także odnotowana modlitwa wiernych, która ma miejsce po upomnieniach i zachętach przełożonego. Uczestniczą w niej również nowo ochrzczeni, zwani po przyjęciu sakramentu oświeconymi. Święty Justyn oddaje intencje tej modlitwy, ale nie podaje jej tekstu ani treści. Wierni wspólnie modlą się „za samych siebie, za nowo ochrzczonego i za wszystkich, gdziekolwiek są obecni, abyśmy zasłużyli na poznanie prawdy, wypełnienie dobrych uczynków i zachowanie przykazań, a przez to osiągnęli wieczne zbawienie" (1 Apologia 65.1). Oratio universalis jest wykonywana przez wszystkich w postawie stojącej (por. 1 Apologia 67.5). Chociaż analizowane źródło nie wskazuje, kto wykonywał poszczególne intencje, jakie było ich uszeregowanie, czy oratio universalis rozpoczynała się

52 Por. D. SARTore, “Chiesa e predicazione”, s. 263.

${ }_{53}$ Por. Homilia z II wieku zwana dawniej „Drugim listem do Koryntian św. Klemensa”, w: M. STAROWIEYSKI (oprac.), Pierwsi świadkowie. Wybór najstarszych pism chrześcijańskich (Ojcowie żywi, t. VIII), thum. A. Świderkówna, Kraków 1988, s. 113-120; M. STAROwIEYSKI, Z historii wczesnego chrześcijaństwa. Biblia, męczennicy, bogowie i inni, Kraków 2015, s. 134.

${ }_{54}$ Por. Meliton z Sardes, Homilia paschalna, w: M. Starowieyski (oprac.) Pierwsi świadkowie. Wybór najstarszych pism chrześcijańskich (Ojcowie żywi, t. VIII), tłum. A. Świderkówna, Kraków 1988, s. 318-353.

55 Por. M. Starowieyski, Z historii wczesnego chrześcijaństwa, s. 153. 
krótką zachętą i czy miała modlitwę na zakończenie (por. OWMR 71), to świadczy o istnieniu w Rzymie, a może i w całym ówczesnym chrześcijańskim świecie, takiej formy modlitwy ${ }^{56}$. Ten element liturgii eucharystycznej jest, jak twierdzi Cesare Giraudo, pierwszorzędnej wartości (di primaria importanza), gdyż podczas sprawowania liturgii eucharystycznej do tej pory lud Boży był adresatem słowa Bożego, a podczas zanoszenia oratio universalis staje się ludem, który artykułuje swój głos, a ten wznosi się ku Bogu. Element ten jest klasyfikowany przez tego badacza jako suppliche ${ }^{57}$.

Nie jest łatwo wskazać źródła oratio universalis. Ten rodzaj modlitwy powstał z refleksji nad nauką zostawioną przez św. Pawła w 1 Liście do Tymoteusza. Apostoł Narodów daje polecenie odnośnie do modlitwy Tymoteuszowi i efeskiej wspólnocie ${ }^{58}$ :

Polecam więc przede wszystkim, by prośby, modlitwy, wspólne błagania, dziękczynienia odprawiane były za wszystkich ludzi: za królów i za wszystkich sprawujących władzę, abyśmy mogli prowadzić życie ciche i spokojne z całą pobożnością i godnością $(1 \mathrm{Tm} 1,2)^{59}$.

Ten tekst z 1 Listu do Tymoteusza nie jest gotową modlitwą liturgiczną ${ }^{60}$, ale nauka św. Pawła odnośnie do takiej formy modlitwy jest obecna w wypowiedziach ojców Kościoła, którzy wzywali do modlitwy za różne grupy osób i w wielu intencjach ${ }^{61}$. To Klemens Rzymski, trzeci następca św. Piotra, w Liście do Kościoła $w$ Koryncie napisanym w latach $95-98^{62}$ i odczytywanym podczas liturgicznych niedzielnych zgromadzeń ${ }^{63}$ umieszcza modlitwę (LIX,3-LXI,3), prośbę do Boga,

${ }^{56}$ Por. E. Mazza, La celebrazione eucaristica. Genesi del rito e sviluppo dell'interpretazione (Liturgia. Studi e sussidi, t. XI), Milano 1996, s. 134.

${ }^{57}$ Por. C. Giraudo, Ascolta, Israele! Ascoltaci, Signore! Teologia e spiritualità della Liturgia della Parola, Città del Vaticano 2008, s. 103-104.

${ }^{58}$ Por. P. PikuŁa, Ażeby nie bluźniono, w: R. Pindel, S. JęDRZEJEwSKi (red.), Biblia i kultura - dia$\log$ czy konflikt? (Hermeneutica et judaica, t. I), Kraków 2008, s. 97.

${ }^{59}$ Cytat z Biblii Tysiąclecia. Pismo Święte Starego i Nowego Testamentu w przekładzie z języków oryginalnych, Poznań 2003.

${ }^{60}$ Por. J. Baumgartner, Die „Preces” in Laudes und Vesper. Ein zurückgewonnenes Element christlichen Gebetsgutes, w: M. KLÖCKENER, H. RENNINGS (red.), Lebendiges Stundengebet. Vertiefung und Hilfe, Freiburg - Basel - Wien 1989, s. 369. s. 48.

${ }^{61}$ Por. V. RafFa, Le intercessioni di Lodi e Vespri, „Ephemerides Liturgicae” LXXXVI (1972),

${ }^{62}$ Por. A. Quacquarelli (red.), I Padri Apostolici. Traduzione, introduzione e note (Collana dei testi patristici, t. V), Roma 1978², s. 47.

${ }^{63}$ Por. Euzebiusz z Cezarei, Historia kościelna, s. 170-171, 276-277. 
aby przyszedł On z pomocą w różnych nieszczęściach ${ }^{64}$. W jednej z jej części jest, jak się wydaje, przedstawiona dość składnie ułożona litania próśb typu pro, która rozpoczyna się słowami:

Prosimy Cię, Panie, bądź „naszym obrońcą i naszą tarczą”. Wybaw tych z nas, którzy są w udręce. Zmiłuj się nad pokornymi. Podnieś tych, którzy upadli. Tym, którzy są w potrzebie, okaż Twe oblicze. Chorych ulecz. Zbłąkanych spośród Twego ludu przywiedź do domu. Nakarm głodnych. Wykup więźniów. Pomóż wstać słabym. Dodaj odwagi małodusznym. „Niechaj poznają wszystkie ludy, że Ty jesteś Bogiem Jedynym”. Że Jezus Chrystus jest Synem Twoim. A my „ludem Twoim i owcami Twojej owczarni" ${ }^{65}$.

Marek Starowieyski w Liście do Kościoła w Koryncie widzi „Wielką modlitwę powszechną" ułożoną na bazie biblijnych cytatów bądź aluzji do Pisma Świętego, do pism judaistycznych i pogańskich ${ }^{66}$. „Wielka modlitwa powszechna” powstała z chrześcijańskiej potrzeby, ale przy wykorzystaniu różnych wyżej wskazanych tekstów. Szczegółowe petycje fragmentu zwanego „Wielką modlitwą” zawierają takie terminy, jak „,zbaw”, „podnieś”, „okaż”, „,ulecz”, „przywiedź”, „nakarm”, „wykup”, „pomóż” i „dodaj”, które wskazują na sytuację, w jakiej znajduje się rzymska wspólnota ${ }^{67}$. Mimo że mamy tak wyjątkowy, cenny tekst modlitwy, ilustrujący wczesny etap rozwoju chrześcijańskiej euchologii, niestety, nie jesteśmy w stanie powiedzieć, jak była ona stosowana ${ }^{68}$.

Poszukując przykładów zapisu oratio universalis czasowo bliskich powstaniu 1 Apologii św. Justyna, należy poddać analizie dziedzictwo Kościoła w północnej Afryce. Dwaj przedstawiciele tego Kościoła, Tertulian w dziełach Apologetyk $(39,1-3)$ i $O$ modlitwie $(29,2)$ oraz Cyprian w $O$ modlitwie Pańskiej (8) i listach $(11,8 ; 59,18 ; 76,7)$, zostawili wzmianki o zanoszeniu przez ówczesnych wiernych modlitwy powszechnej. Przytoczone dzieła wskazują, zdaniem Paula de Clercka,

${ }^{64}$ Por. M. SIEŃKOwsKi, Elementy duchowości chrześcijańskiej w „, Liście do Kościoła w Koryncie” św. Klemensa Rzymskiego, „Ełckie Studia Teologiczne” III (2002), , 95.

${ }^{65}$ Klemens Rzymski, List do Kościoła w Koryncie LIX,4, thum. A. Świderkówna, w: M. STAROWIEYSKI (oprac.), Pierwsi świadkowie. Wybór najstarszych pism chrześcijańskich (Ojcowie żywi, t. VIII), Kraków 1988, s. 105-106.

${ }^{66}$ Por. tami̇e, s. 486.

${ }^{67}$ Por. Clemens PP I, Lettera ai Corinzi di Clemente Romano, E. Peretto (oprac.), (Scritti delle origini cristiane, t. XXIII), Bologna 1999, s. 91-97, 279.

${ }_{68}$ Por. P. De CleRCK, La ,prière universelle” dans les liturgies latines anciennes. Témoignages patristiques et textes liturgiques (Liturgiewissenschaftliche Quellen und Forschungen, t. LXII), Münster Westfalen 1977, s. 5. 
że afrykańscy chrześcijanie stosowali w liturgii oratio fidelium. Była to modlitwa typu supplicare pro lub orare pro bądź też lista intencji ${ }^{69}$.

\section{Pocalunek pokoju ${ }^{70}$}

Pocałunek pokoju jest znakiem, który kończy oratio universalis. „Na zakończenie zaś modlitw pozdrawiamy się wzajemnie pocałunkiem pokoju" (1 Apologia 65.2). Byłby więc pocałunek pokoju zwieńczeniem wszystkich intencji zanoszonych przez wiernych. Święty Justyn jest pierwszym chrześcijańskim autorem, który zaświadcza o pocałunku pokoju w liturgii. Pocałunek ten przekazywany jest także oświeconym przed rozpoczęciem przynoszenia darów ${ }^{71}$. Trudno jest jednak jednoznacznie określić znaczenie tego znaku. W komentarzu do tłumaczenia 1 Apologii Leszek Misiarczyk mówi, że w pocałunku prawdopodobnie należy widzieć znak pokoju ${ }^{72}$. Badając tekst 1 Apologii, zauważamy, że z jednej strony pocałunek pokoju jest wyraźnie odnotowany, w momencie gdy oświeceni uczestniczą po raz pierwszy w Eucharystii, z drugiej zaś strony nic się o nim nie mówi, gdy św. Justyn przedstawia liturgię eucharystyczną składaną w dzień Słońca ${ }^{73}$. Skąd ta luka? Zdaniem liturgisty Giovanniego di Napoli już w czasach Justyna wśród współczesnych mu apologetów pojawiały się trudności z rozumieniem tego liturgicznego gestu ${ }^{74}$. Chrześcijanie byli oskarżani o niemoralność małżeńską, kazirodztwo i kanibalizm (por. Teofil z Antiochii, Do Autolika III.4.1) ${ }^{75}$, a sam pocałunek pokoju wymieniany w zgromadzeniu liturgicznym, zdaniem broniącego chrześcijan Atenagorasa z Aten, dla którego jest on wyrazem szacunku, mógł być uzewnętrznieniem znieważenia ciała i zaprzeczeniem chrześcijańskiej nauki

69 Por. P. De ClerCK, La „prière universelle” dans les liturgies latines anciennes, s. 18-22.

${ }^{70}$ Skromny artykuł na temat pocałunku pokoju został opublikowany wiele lat temu na łamach czasopisma „Ruch Biblijny i Liturgiczny”. T. SzWAGRzYK, Pocalunek pokoju, „,Ruch Biblijny i Liturgiczny" XII (1959) nr 5, s. 520-523.

${ }^{71}$ Por. K. LIJKA, Pocalunek pokoju w liturgii eucharystycznej i jego symbolika, „Teologiczne Studia Siedleckie” XII (2015) 12, s. 190.

72 Por. Justyn męczennik, 1 i 2 Apologia. Dialog z Żydem Tryfonem, s. 86.

${ }^{73}$ Por. G. Di NAPOLI, Pacis concludentis signaculo. Lo scambio del bacio di pace nella liturgia eucaristica tra limitazioni e ri-significazione, „Rivista Liturgica” XCVII (2010) nr 4, s. 501.

${ }^{74}$ Por. G. Di NAPOLI, Da precibus finitis a ante confecta mysteria: la prima sostanziale metamorfosi del bacio di pace, „Rivista Liturgica” CI (2014) nr 4, s. 686.

75 Por. Teofil z Antiochin, Do Autolika, w: Pierwsi apologeci greccy. Kwadratus, Arystydes z Aten, Aryston z Pelli, Justyn Męczennik, Tacjan Syryjczyk, Milcjades, Apolinary z Hierapolis, Teofil z Antiochii, Hermiasz, tłum. wstępy i komentarze L. MisiarczYK, (Biblioteka Ojców Kościoła, t. XXIV), Kraków 2004, s. 441. 
(por. Prośba za chrześcijanami 32) ${ }^{76}$. Notabene dzieło to zostało napisane w 177 roku, a więc zaledwie kilkanaście lat po apologiach Justyna ${ }^{77}$.

Jakie ma pochodzenie ten liturgiczny gest? Grek Herodot (zm. ok. 426 r. przed Chr.), zwany ojcem historii i geografii, w swoich Dziejach odnotował zwyczaj całowania się nawzajem w usta przez Persów $(\text { Dzieje } 1,134)^{78}$. Liturgia synagogalna nie zna pocałunku, a ,powszechnie przestrzegane formy gościnności nie nakazywały witać gościa pocałunkiem"79. O pocałunku świętym jest mowa w Liście do Rzymian 16,16, w 1 Liście do Koryntian 16,20 i 1 Liście do Tesaloniczan 5,26. Zdaniem Heinza Schürmanna, w czasach apostolskich w środowisku chrześcijan niepochodzących z judaizmu na zakończenie eucharystycznej agapy pojawia się pożegnalny pocałunek, znak miłości braterskiej we wspólnocie. Znak ten wyraża przekazanie daru Ducha Świętego ${ }^{80}$. Natomiast znany biblista Joseph Fitzmyer, analizując List do Rzymian, dostrzega św. Pawła, który podczas tworzenia swojego dziedzictwa epistolarnego wprowadza do niego prawdopodobnie gest liturgiczny wykonany podczas celebracji Wieczerzy Pańskiej ${ }^{81}$. Wspomniany już Giovanni di Napoli twierdzi, że pocałunek pokoju rodzi się wśród chrześcijan, w momencie gdy rozpoznają oni, że tworzą chrześcijańską grupę, którą łączy braterstwo. Ta konstatacja staje się podstawą do wyrażania braterskiej więzi przez gest pocałunku, czy to w czasie liturgii, czy w życiu publicznym ${ }^{82}$. Znak ten byłby więc wyrazem miłości braterskiej.

Analizując rozwój tego gestu, należy dostrzec, że tak częste wspominanie o nim, o przestrzeganiu w nim zasad czystości, szczerości, pokoju i nieobłudnej miłości, jak o tym pisze chociażby Orygenes, dowodzi niezrozumienia jego znaczenia i praktyki przez wielu chrześcijan ${ }^{83}$. Źródło bliskie Orygenesowi, tzn.

76 Por. Atenagoras z Aten, Prośba za chrześcijanami, w: tenże, Prośba za chrześcijanami. $O$ zmartwychwstaniu umartych, tłum., wstępem i przypisami opatrzył S. KaLInKowsKi, Warszawa 1985, s. 75-76.

77 Por. S. KalinKowsKi, Wczesnochrześcijańska apologia grecka (II-V w.). Zarys rozwoju, w: Atenagoras z Aten, Prośba za chrześcijanami. O zmartwychwstaniu umartych, tłum. wstępem i przypisami opatrzył S. KaLInKowski, Instytut Wydawniczy PAX, Warszawa 1985, s. 11.

78 Por. Herodot, Dzieje, thum. S. Hammer, R. Turasiewicz (oprac.), Wrocław 2006, s. 74.

79 Ewangelia wedtug św. Eukasza. Rozdziaty 1-11. Wstęp. Przekład z oryginatu. Komentarz, F. Mickiewicz, cz. 1 (Nowy komentarz biblijny. Nowy Testament, t. III/1), Częstochowa 2011, s. 404.

${ }^{80}$ Por. H. Schürmann, Prima Lettera ai Tessalonicesi (Commenti spirituali del Nuovo Testamento, t. XIII), tłum. B. Da Malè, Roma 1965, s. 109-110.

81 Por. J.A. Fitzmyer, Lettera ai Romani. Commentario critico-teologico, tłum. E. Gatti, edizione italiana A. Pitta (red.), Piemme, Casale Monferrato 1999, s. 877.

82 Por. G. Di Napoli, Pacis concludentis signaculo, s. 498.

83 Por. Orygenes, Komentarz do Listu św. Pawła do Rzymian 10,33 (Pisma Starochrześcijańskich Pisarzy, t. LVII, cz. 2), tłum. S. Kalinkowski, wstęp E. Stanula, S. Kalinkowski, E. Stanula (oprac.), Wydawnictwa Akademii Teologii Katolickiej, Warszawa 1994, s. 546-547. 
Tradycja Apostolska, jest świadkiem ewolucji tego znaku, a zarazem jego znaczenia. $\mathrm{Z}$ tekstu wynika, że pocałunek pokoju otrzymuje od wszystkich nowo wyświęcony biskup (por. Tradycja Apostolska 3 3 $^{84}$. Byłby to więc znak przyjęcia nowego pasterza i składanych mu serdecznych życzeń. Katechumeni nie składają sobie pocałunku (por. Tradycja Apostolska 17), gdyż wymieniany przez nich nie miałby jeszcze waloru świętości. Natomiast wierni witają się pocałunkiem, który składają mężczyźni mężczyznom, a kobiety kobietom, ale mężczyźni w ten sposób nie witają kobiet (por. Tradycja Apostolska 17). Byłby to więc gest służący powitaniu. Także podczas udzielania sakramentów wtajemniczenia biskup, namaszczając czoło poświęconym olejem, daje pocałunek bierzmowanemu i mówi „Pokój z tobą”, i sam słyszy odpowiedź „I z duchem twoim” (por. Tradycja Apostolska 21). Pocałunek ten należy widzieć jako wyraz przyjęcia neofity do wspólnoty wiernych ${ }^{85}$.

\section{Zakończenie}

Zakończenie tego referatu wygłoszonego podczas konferencji naukowej pt. Genetyka liturgii powinno wybrzmieć w następujący sposób: Elementy celebracji: lektura biblijna, przepowiadanie, oratio universalis i pocałunek pokoju, które poddano analizie, odsyłają nas do myśli i praktyki Kościoła. Wskazane elementy celebracji niosą w sobie wyraz wiary - teologii, która wyrażona w liturgicznej czynności zaowocowała euchologią, rubryką i strukturą eucharystycznej liturgii. Możliwe, że szeroka definicja pojęcia „gen” pozwoliłaby liturgiście w czynnościach: lektury biblijnej, przepowiadania, oratio universalis i pocałunku pokoju dostrzec „geny”, które połączone w łańcuch zawierają w sobie i wyrażają bogactwo istotnych treści prawd celebrowanych w Kościele. Niemniej jednak celem przedstawionego referatu nie jest próba przypisywania terminu ,gen” do konkretnej czynności liturgicznej. Celem nie jest także próba wskazania, które elementy w eucharystycznej liturgii moglibyśmy nazwać „elementami dziedziczonymi”. Kończąc, pragnę aby słuchacz dostrzegł źródło - teologię liturgiczną, które wybiło, zanim św. Justyn Męczennik napisał 1 Apologię i zanim zredagowano czcigodne sakramentarze Kościoła zwane źródłami liturgicznymi. Źródło to ciągle bije, poi i determinuje egzystencję. Jak naucza nasz Jezus Chrystus Samarytankę pod Sychem, a w Sychem urodził się Ju-

${ }^{84}$ Por. HiPolit Rzymski, Tradycja Apostolska. Wstep, przekład, komentarz, thum. H. PAPROCKI, „Studia Theologica Varsaviensia” 14 (1976) nr 1, s. 151. s. 776 .

85 Por. S. PARENTI, Il bacio di pace nelle liturgie orientali, „Rivista Liturgica” CI (2014) nr 4, 
styn w pogańskiej rodzinie, darem ofiarowanym przez Zbawiciela człowiekowi jest woda, która w obdarzonym tymże darem staje się ,źródłem wody wytryskującej ku życiu wiecznemu" (J 4,14).

\title{
Streszczenie
}

W Apologii pierwszej św. Justyna Męczennika znajdujemy informacje o chrześcijanach i ich praktyce sprawowania Eucharystii. W dziele tym została opisana także lektura słowa, która składała się z jednej lektury, przepowiadania, oratio universalis, a także z pocałunku pokoju w czasie udzielania sakramentu inicjacji w czasie Mszy Świętej. Autor artykułu, korzystając ze źródeł wcześniejszych niż 1 Apologia, jak i tych datowanych na kilkanaście lub kilkadziesiąt lat po niej, starał się przybliżyć ówczesny stan liturgii słowa wraz z jej elementami oraz jej rozwój. Pozwoliło to na wskazanie i przybliżenie istotnych składników czynności liturgicznych sprawowanych w czasie Eucharystii celebrowanej w II wieku.

Słowa kluczowe: św. Justyn, 1 Apologia, lektura biblijna, przepowiadanie, oratio universalis, pocałunek pokoju.

\section{Essential constituents of the content of the liturgical activities performed according to Justin Martyr and their evolution}

\begin{abstract}
In the First Apology of Justin Martyr we find information about Christians and their practice of celebrating the Eucharist. In this work, the reading of the word was also described, which consisted of: one reading, preaching, oratio universalis, and also the kiss of peace during the administration of the sacrament of initiation together with the Holy Mass. The author of the article, using sources earlier than the First Apology, as well as those dated over a dozen or several decades after it, tries to present the contemporary state of the liturgy of the word along with its elements and its development. This allowed the identification and closer approach to the essential components of the liturgical activities performed during the Eucharist celebrated in the second century.
\end{abstract}

Keywords: Saint Justin, the First Apology, Bible reading, preaching, oratio universalis, kiss of peace. 


\section{Bibliografia}

Pismo Święte Starego i Nowego Testamentu w przekładzie z języków oryginalnych, oprac. zespół biblistów polskich z inicjatywy Benedyktynów Tynieckich. Wydanie piąte na nowo opracowane i poprawione, Pallottinum, Poznań 2003.

\section{Źródła}

Atenagoras z Aten, Prośba za chrześcijanami, w: tenże, Prośba za chrześcijanami. O zmartwychwstaniu umartych, tłum. wstępem i przypisami opatrzył S. KALINKOwSKI, Warszawa 1985, s. 25-80.

Didaskalia, czyli Katolicka nauka dwunastu apostolów i świętych uczniów Zbawiciela naszego, w: M. Michalski, Antologia literatury patrystycznej, t. I, Warszawa 1975, s. 316-331.

Euzebiusz z Cezarei, Historia kościelna, tłum. A. Caba na podstawie thum. A. Lisieckiego (Źródła myśli teologicznej, t. LXX), Kraków 2013.

Herodot, Dzieje, thum. S. Hammer, R. Turasiewicz (oprac.), Wrocław 2006.

Hipolit Rzymski, Tradycja Apostolska. Wstep, przektad, komentarz, thum. H. PAPROCKI, „Studia Theologica Varsaviensia” 14 (1976) nr 1, s. 145-169.

Homilia z II wieku zwana dawniej „Drugim listem do Koryntian św. Klemensa”, w: M. Starowieyski (oprac.), Pierwsi świadkowie. Wybór najstarszych pism chrześcijańskich (Ojcowie żywi, t. VIII), tłum. A. Świderkówna, Kraków 1988, s. 113-120.

Justyn męCZennik, 1 i 2 Apologia. Dialog z Żydem Tryfonem, thum. i oprac. L. MiSIARCZYK, Warszawa 2012.

Klemens Rzymski, List do Kościoła w Koryncie, w: M. Starowieyski (oprac.), Pierwsi świadkowie. Wybór najstarszych pism chrześcijańskich (Ojcowie żywi, t. VIII), tłum. A. Świderkówna, Kraków 1988, s. 61-109.

Clemens PP I, Lettera ai Corinzi di Clemente Romano, E. Peretto (oprac.), (Scritti delle origini cristiane, t. XXIII), Bologna 1999.

Księga pontyfików 1-96 (do roku 772), tłum. P. Szewczyk, M. Jesiotr; M. OżóG, H. Pietras (oprac.), (Synody i kolekcje praw, t. IX), Kraków 2014.

Meliton z Sardes, Homilia paschalna, w: M. Starowieyski (oprac.), Pierwsi świadkowie. Wybór najstarszych pism chrześcijańskich (Ojcowie żywi, t. VIII), thum. A. Świderkówna, Kraków 1988, s. 318-353.

Ogólne wprowadzenie do Mszału Rzymskiego. Z trzeciego wydania Mszatu Rzymskiego, Rzym 2002, oraz Wskazania Episkopatu Polski, Poznań 2006. 
Orygenes, Komentarz do Listu św. Pawła do Rzymian (Pisma Starochrześcijańskich Pisarzy, t. LVII, cz. 2), thum. S. Kalinkowski, wstęp E. Stanula, S. KALINKOWSKi, E. STANULA (oprac.), Warszawa 1994.

Quacquarelli A. (red.), I Padri Apostolici. Traduzione, introduzione e note (Collana dei testi patristici, t. V), Roma $1978^{2}$.

Quintus Septimus Florens Tertullianus, De anima, PL, t. II, kol. 641-752.

Quintus Septimus Florens Tertullianus, De anima, w: tenże, Opera dogmatica: De anima - De carnis resurrectione - Adversus Praxean (Scriptores Arficae Christiani, t. III/2.b), C. Moreschini, P. Podolak (red.), Roma 2010, s. 48247.

Tertulian, Przeciw Marcjonowi (Pisma Starochrześcijańskich Pisarzy, t. LVIII), tłum. S. Ryzner, wstęp, oprac. W. Myszor, Warszawa 1994.

Sokrates Scholastyk, Historia Kościoła, tłum. S. Kazikowski, Warszawa 1972.

Teofil z Antiochi, Do Autolika, w: L. Misiarczyk (tłum. wstępy i komentarze), Pierwsi apologeci greccy. Kwadratus, Arystydes z Aten, Aryston z Pelli, Justyn Męczennik, Tacjan Syryjczyk, Milcjades, Apolinary z Hierapolis, Teofil z Antiochii, Hermiasz (Biblioteka Ojców Kościoła, t. XXIV), Kraków 2004, s. 385-464.

\section{Opracowania (publikacje wybrane)}

Baumgartner J., Die „Preces” in Laudes und Vesper. Ein zurückgewonnenes Element christlichen Gebetsgutes, w: M. KLÖCKENER, H. RenNINGs (red.), Lebendiges Stundengebet. Vertiefung und Hilfe, Herder, Freiburg - Basel - Wien 1989, s. 368-397.

BeA A., Il valore pastorale della Parola di Dio nella sacra liturgia, w: La restaurazione liturgica nell'opera di Pio XII. Atti del Primo Congresso Internazionale di Liturgia Pastorale, Assisi - Roma 18-22 settembre 1956, Centro di Azione Liturgica, Genova 1957, s. 95-112.

Bonneau N., Il Lezionario domenicale. Origine struttura teologia (Studi i ricerche di liturgia), thum. R. Fabbri, Bologna 2012.

BRADSHAw P.F., W poszukiwaniu początków kultu chrześcijańskiego. Źródla i metody badań wczesnej liturgii (Źródło i szczyt), thum. P. Kaznowski, M. Koza, Kraków 2016.

Czerwik S., Wiara w obecność Chrystusa w sprawowaniu Eucharystii. Perspektywa historyczna, w: S. KopereK (przew. zesp. red.), Eucharystia na oltarzu świata (Studia, t. XIV), Kraków 2006, s. 173-192. 
De CleRCK P., La „prière universelle” dans les liturgies latines anciennes. Témoignages patristiques et textes liturgiques (Liturgiewissenschaftliche Quellen und Forschungen, t. LXII), Münster Westfalen 1977.

DE ZAN R., Leggere la Bibbia nella liturgia, „Rivista Liturgica” LXXXVIII (2001), s. 869-880.

Di NAPOLI G., Da precibus finitis a ante confecta mysteria: la prima sostanziale metamorfosi del bacio di pace, „Rivista Liturgica” CI (2014) nr 4, s. 685-702.

DudzIK W., Liturgia słowa pierwszych chrześcijan, „Teofil” (2007) nr 1 (25), s. $123-134$.

GiRaudo C., Ascolta, Israele! Ascoltaci, Signore! Teologia e spiritualità della Liturgia della Parola, Città del Vaticano 2008.

Jungmann J.A., La Messa nel corso dei secoli. La Messa e la comunità della Chiesa. La Messa didattica, thum. Benedettini del Monastero di. S. Paolo in Sorrento, t. I, Torino $1963^{2}$.

LIJKA K., Pocałunek pokoju w liturgii eucharystycznej i jego symbolika, „Teologiczne Studia Siedleckie” XII (2015) 12, s. 189-205.

NADOLSKI B., Ewangeliarz - więcej niż księga święta: szacunek wobec księgi Ewangelii, Poznań 2000.

Parenti S., Il bacio di pace nelle liturgie orientali, „Rivista Liturgica” CI (2014) nr 4, s. 775-788.

Perrot С ère, „La Maison-Dieu” (1976) nr 126, s. 24-41.

Simonelli C., Prendere parola nella liturgia. Piste di ricerca, „Rivista Liturgica” CIV (2017), s. 45-63.

Sobeczko H.J., Liturgia słowa Bożego w tradycji rzymskiej do reformy II Soboru Watykańskiego, w: A. ŻĄDŁo (red. nauk.), Praedicamus Christum crucifixum. Stowo Boże w liturgii Kościoła. Księga Jubileuszowa dedykowana Księdzu Arcybiskupowi Damianowi Zimoniowi Metropolicie Katowickiemu w 25. rocznicę święceń biskupich, Katowice 2010, s. 107-123.

Sobeczko H.J., Stowo Boże w tradycji Kościoła sprawującego liturgie, w: A. ŻĄDŁo (red.), Słowo Boże w liturgii i życiu Kościoła (Kościół w Trzecim Tysiącleciu, t. V), Katowice 2006, s. 42-66.

SzwagrzyK T., Pocalunek pokoju, „Ruch Biblijny i Liturgiczny” XII (1959) nr 5, s. 520-523. 
JAROSŁaW Superson SAC, ur. 1967 r., tytuł doktora nauk liturgicznych otrzymał w Papieskim Instytucie św. Anzelma w Rzymie w 2003 r. Adiunkt przy Katedrze Teologii Liturgii Wydziału Teologicznego Uniwersytetu Papieskiego Jana Pawła II w Krakowie. Redaktor tematyczny czasopisma „Ruch Biblijny i Liturgiczny”. Jest autorem książek: Historia uroczystości Jezusa Chrystusa Króla Wszechświata, Wydawnictwo WAM, Kraków 2005; I Nieszpory uroczystości Jezusa Chrystusa Króla Wszechświata w Liturgia horarum. Źródta - historia - teologia, Wydawnictwo Naukowe PAT, Kraków 2007; Historia stuły, Wydawnictwo WAM, Kraków 2011; Oltarz, krzyż i kierunek zanoszonych modlitw, Homo Dei, Kraków 2014; Wersety psalmiczne w preces Godzin kanonicznych, Tyniec Wydawnictwo Benedyktynów, Kraków 2015. 